\title{
Badanie kompozytowych konstrukcji lotniczych z wykorzystaniem metod fuzji danych dla zobrazowania uszkodzeń i analizy sygnałowej
}

\author{
Inspection of composite aerospace structures \\ with use of data fusion for damage visualization \\ and signal analysis
}

\section{Streszczenie}

W pracy zaproponowano sposób trójwymiarowego zobrazowania uszkodzeń elementów kompozytowych, z wykorzystaniem sekwencji ultradźwiękowych skanów B, który może być pomocny $w$ badaniach nieniszczących. Zaproponowaną metodę zaprezentowano na przykładzie ultradźwiękowego badania próbki wykonanej kompozytu epoksydowego wzmocnionego włóknem węglowym, w której wprowadzono uszkodzenia udarowe BVID. Wizualizacja 3D uszkodzenia, polegająca na agregacji sekwencji skanów w trybie B w postaci tensora oraz progowej filtracji poszczególnych elementów 3D, pozwala m.in. na zwymiarowanie uszkodzeń i określenie głębokości ich zalegania. Dzięki niskiemu kosztowi obliczeniowemu, metoda ta może być zastosowana $\mathrm{w}$ badaniach ultradźwiękowych w trybie czasu rzeczywistego, dając operatorom dodatkowe narzędzie zwiększające jakość uzyskiwanych wyników.

Słowa kluczowe: kompozyty; badania ultradźwiękowe; analiza obrazu
Abstract

The paper presents an approach to 3D reconstruction of a sequence of ultrasonic B-Scans for the purpose of aiding nondestructive testing of composites. For testing the algorithm, the results of ultrasonic testing of carbon fiber reinforced polymer specimen with barely visible impact damage was used. 3D visualisation of damage based on image thresholding and volume rendering facilitates interpretation of ultrasonic data and can be useful in precise assessment of a flaw size and its depth. Owing to the low computational complexity of the proposed algorithm it could be applied during real-time ultrasonic inspections of composite structures.

Keywords: composites; ultrasonic inspection; image processing

\section{Wstęp}

Materiały kompozytowe dzięki ich licznym zaletom są szeroko rozpowszechnione $w$ różnych gałęziach przemysłu. Cechują się one dużą wytrzymałością przy relatywnie niewielkiej masie, co pozwala stosować je m.in. w produkcji komponentów statków powietrznych, kadłubów łodzi, czy przemyśle motoryzacyjnym. Jednakże są one podatne na powstawanie uszkodzeń, zarówno w trakcie produkcji jak również w trakcie ich eksploatacji, o charakterze odmiennym od spotykanym dotąd przy zastosowaniu stopów metali. Do głównych uszkodzeń i defektów kompozytów należą: porowatość, wtrącenia ciał obcych, rozwarstwienia czy odklejenia. W celu detekcji większości z wyżej wymienionych uszkodzeń konieczne jest stosowanie czasochłonnych i zaawansowanych metod badań nieniszczących. Jednym

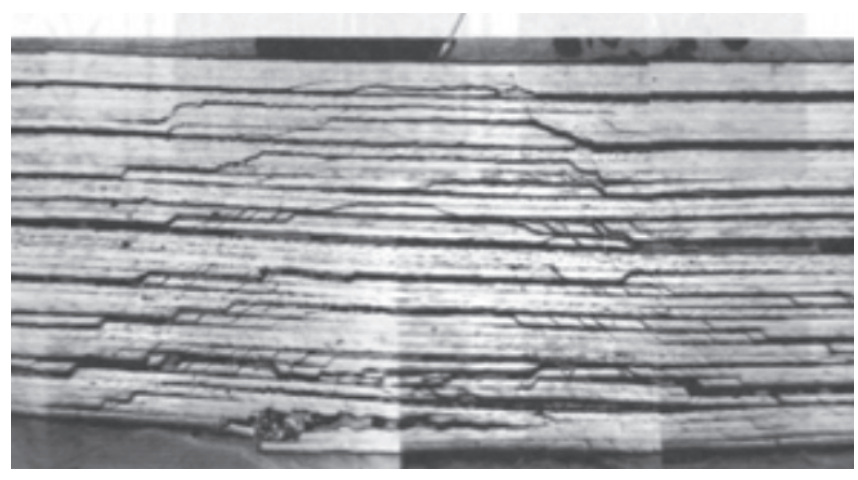

Rys. 1. Uszkodzenie BVID w kompozycie CFRP [1] Fig. 1. BVID in the CFRP composite [1]

Ppłk dr inż. Krzysztof Dragan; dr Michał Dziendzikowski; mgr. inż. Marek Chalimoniuk - Instytut Techniczny Wojsk Lotniczych; mgr inż. Angelika Wronkowicz - Politechnika Śląska; Krzysztof Goździcki - NDT-NET Sp. z o.0.; ppłk dr hab. inż. Andrzej Leski - Wojskowa Akademia Techniczna.

Autor korespondencyjny/Corresponding author: krzysztof.dragan@itwl.pl 
z rodzajów uszkodzeń, często napotykanych w eksploatacji elementów kompozytowych są uszkodzenia powstałe wskutek udarów o niskich energiach. Uszkodzenia te są niemal niewidoczne na powierzchni elementu, skąd wywodzi się ich angielski termin BVID - Barely Visible Impact Damage (rys. 1), powodują jednak powstanie sieci pęknięć matrycy oraz rozwarstwień wewnątrz elementu, co może doprowadzić do znacznego zmniejszenia ich wytrzymałości.

Materiały kompozytowe są również stosowane do budowy elementów statków powietrznych przenoszących znaczne obciążenia. $Z$ tego względu wymagana jest ich regularna diagnostyka oraz odpowiednio wczesne wykrycie uszkodzeń, np. typu BVID, w celu zapobiegnięcia zdarzeniom katastroficznym. Jedną z metod, które są często stosowane do diagnostyki elementów wykonanych z materiałów kompozytowych jest metoda ultradźwiękowa (UT) $[2 \div 10]$.

Przykładowy schemat badania ultradźwiękowego przedstawiony został na rysunku (rys. 2). Głowica pomiarowa, której elementem aktywnym jest przetwornik piezoelektryczny umożliwiający wzajemne przekształcanie przyłożonego doń napięcia elektrycznego $U$ oraz jego odkształceń, generuje w badanym elemencie falę sprężystą. Najczęściej wykorzystywane są fale podłużne o częstotliwościach w zakresie 1-5 MHz.

W przypadku badania jednym przetwornikiem w tzw. trybie pulse-echo $w$ zarejestrowanym na przetworniku przebiegu czasowym napięcia, tzw. skanie A, wyróżnić można co najmniej dwie składowe (rys. 2):

- sygnał wejściowy pochodzący od odbicia wzbudzonej fali sprężystej od powierzchni do której przyłożono głowicę ultradźwiękową;

- tzw. echo od dna związane z odbiciem fali sprężystej od przeciwległej powierzchni badanego elementu.
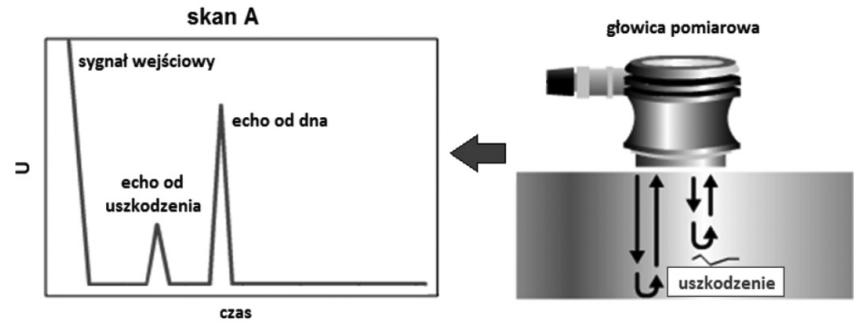

Rys. 2. Schematyczne przedstawienie sygnału rejestrowanego przez głowicę ultradźwiękową [11]

Fig. 2. Schematic view of the ultrasonic signal collected in the ultrasonic transducer [11]

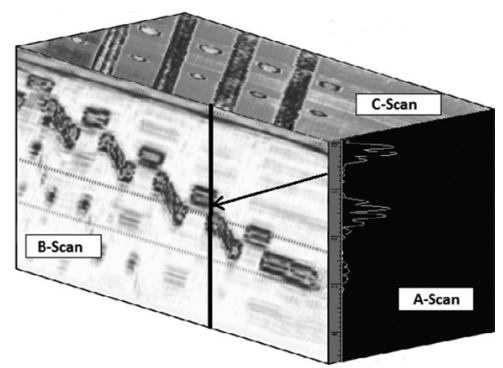

Rys. 3. Przykłady zobrazowania wyników badań ultradźwiękowych [12]

Fig. 3. Examples of ultrasonic data visualization [12]

Jeżeli sonda znajduje się bezpośrednio nad uszkodzeniem, na skanie A wyróżnić można dodatkowo sygnału pochodzący od fali odbitej od niego (rys. 2). Położenie dodatkowego echa sygnału pozwala uzyskać informację o głębokości na której znajduje się uszkodzenie pod badaną powierzchnią. Istotne informacje uzyskać można również z wartości amplitudy oraz fazy echa sygnału. Złożenie skanów A zarejestrowanych wzdłuż wybranej ścieżki przesuwu przetwornika, pozwala uzyskać tzw. skan w trybie B umożliwiający zobrazowanie przekroju danego elementu wzdłuż tej drogi (rys. 3). Każdy ze skanów A tworzy jedną linię przekroju, wzdłuż której intensywność kolorów skanu w trybie B zależy od amplitudy sygnału w poszczególnych chwilach czasu (rys. 2). Wymiarowanie uszkodzeń umożliwia tzw. zobrazowanie w trybie C (Rys. 3). Powstaje ono w wyniku przetwarzania skanów A zarejestrowanych dla zadanego obszaru badanego elementu. Barwa obrazu w danym punkcie uzależniona jest od szczegółów przebiegu czasowego sygnału zarejestrowanego przez sondę ultradźwiękową umieszczoną w tym punkcie.

\section{Opis badania}

Badania przeprowadzono na próbce kompozytu węglowego CFRP, wzmocnionego włóknem węglowym o osnowie epoksydowej. Próbkę o wymiarach 100 x 150 × 4 mm, wykonano z 32 warstw laminatu MTM45-1 o symetrycznym ułożeniu warstw w sekwencji [0, 45, 90,-45]S (Rys. 4).

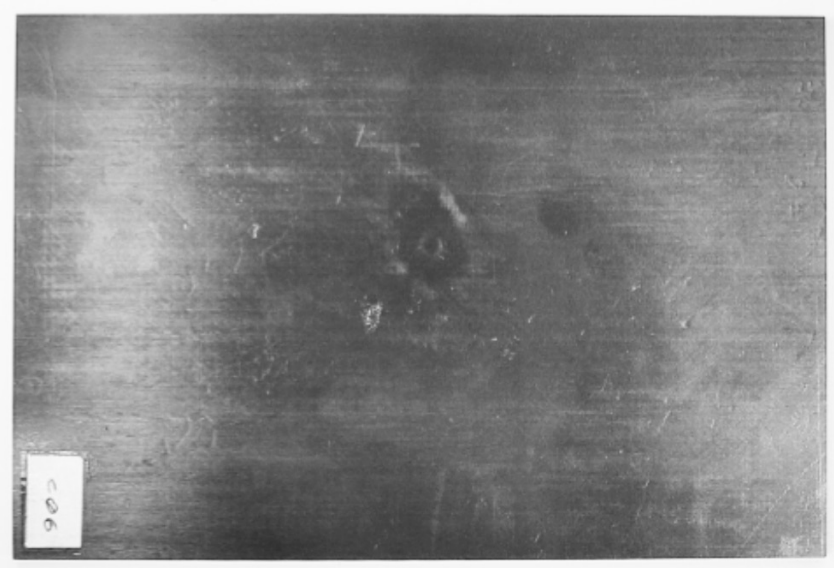

Rys. 4. Widok próbki CFRP

Fig. 4. CFRP specimen visualization

Próbkę poddano uderzeniu o energii $30 \mathrm{~J}$, które spowodowało powstanie uszkodzenia BVID. Badania ultradźwiękowe przeprowadzono z zastosowaniem skanera Flawlnspecta. Głowica urządzenia zawiera 128 elementów aktywnych, co umożliwia aktywne formowanie wiązki ultradźwiękowej w zakresie częstotliwości 1-15 MHz. Badanie wykonano w częstotliwości $5 \mathrm{MHz}$. Przykładowe rezultaty badania ultradźwiękowego w formie ciągu zobrazowania w trybie B próbki przedstawiono poniżej (Rys. 5).

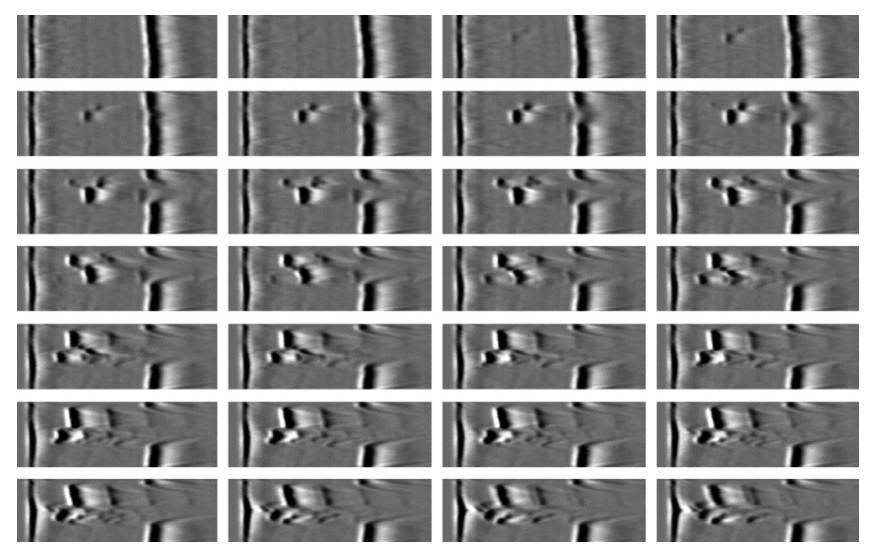

Rys. 5. Przykładowy układ wyników w zobrazowaniu w trybie B Fig. 5. Exemplary B-scans result of the ultrasonic inspection

\section{Zobrazowanie 3d uszkodzeń na podstawie fuzji danych}

Rezultaty badania próbki (zobrazowanie w trybie B) przedstawiają ultradźwiękowy obraz kolejnych przekrojów próbki. Na poszczególnych obrazach wyróżnić można zarówno echa od dna, jak również składowe sygnału pochodzące od odbi- 
cia fali sprężystej od uszkodzeń (Rys. 6). Informacja niesiona przez poszczególne skany $B$, została zagregowana w formie macierzy 3D (Rys. 7(a)). Takie przedstawienie wyników badania umożliwia wstępną wizualizację 3D uszkodzenia. Zastosowanie filtrów progowych dla wartości intensywności poszczególnych pikseli zawartych w zagregowanej macierzy 3D postaci:

$$
I=\left\{\begin{array}{lll}
0 & \text { dla } & I<T \\
I & \text { dla } & I \geq T
\end{array}\right.
$$

gdzie T jest tzw. progiem filtracji, pozwala uzyskać mapę obszarów (Rys. 7(b)), dla których wystąpiło odbicie fali sprężystej, czyli brzegów próbki oraz uszkodzeń. Próg jest analogiczny do klasycznego kryterium filtracji sygnału przy zobrazowaniu w trybie C głębokości zalegania uszkodzeń - należy wówczas określić minimalną wartość amplitudy sygnału, która jest uważana za odbicie od uszkodzenia. Próg ten jest zazwyczaj dobierany indywidualnie w zależności od warunków wykonywania badania, w tym rodzaju materiału, zastosowanych głowic, czy poziomu szumu pomiarowego.

Po zastosowaniu filtracji, w zobrazowaniu 3D (Rys. 7(b)) widoczne jest uszkodzenie BVID oraz płaszczyzny brzegowe próbki. Po usunięciu bloków macierzy odpowiadających odbiciom od płaszczyzn próbki, możliwe jest zobrazowanie 3D fali rozproszonej na uszkodzeniu. Operacja ta odpowiada filtracji czasowej sygnału, którą można uzyskać za pomocą odpowiedniej konfiguracji urządzenia skanującego.

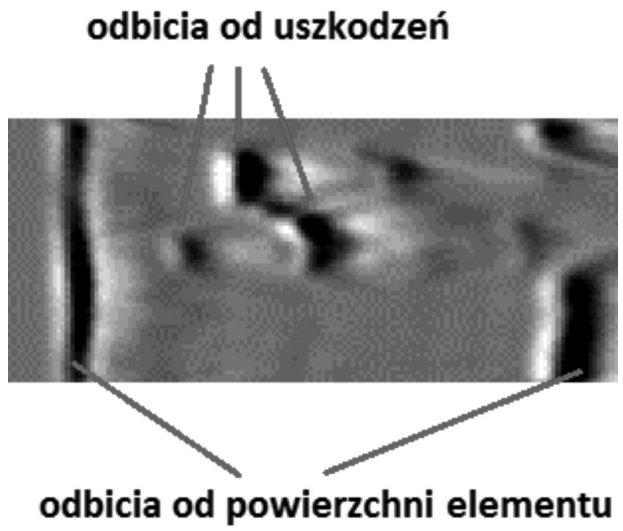

Rys. 6. Składowe sygnału dla przykładowego zobrazowania w trybie B Fig. 6. Data components of the exemplary image in the B-scan a)

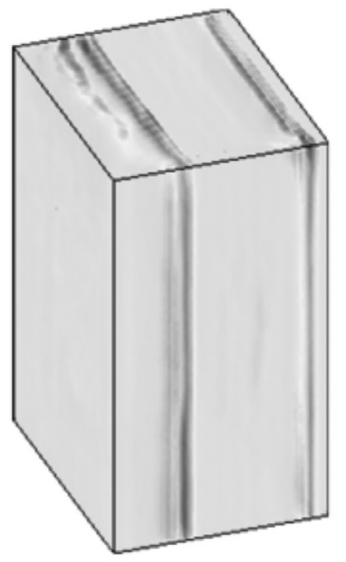

b)

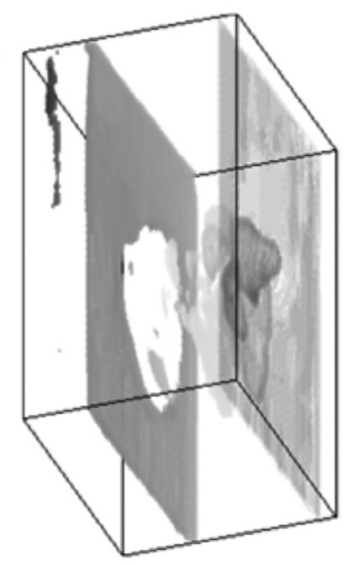

Rys. 7. Trójwymiarowe złożenie danych w trybie B: (a) macierz 3D przed filtracją oraz (b) macierz 3D po filtracji

Fig. 7. 3D data compound in the B-scan: (a) 3D non filtered matrix and (b) 3D filtered matrix

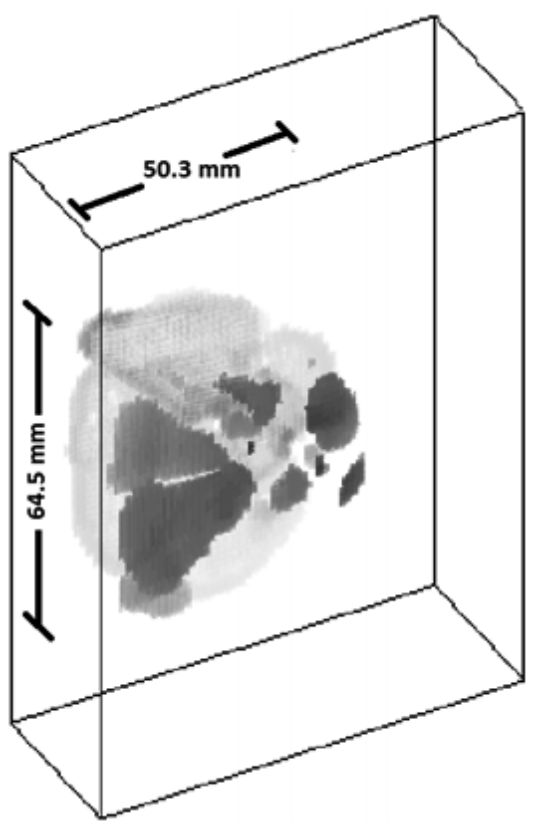

Rys. 8. Zobrazowanie 3D uszkodzenia uzyskane na podstawie złożenia zobrazowania $w$ trybie $B$

Fig. 8. 3D data visualization based on B-scan data compound

\section{Podsumowanie}

W pracy przedstawiono sposób agregacji danych uzyskanych podczas ultradźwiękowego badania uszkodzeń BVID elementów kompozytowych. Przedstawiona metoda charakteryzuje się niskim kosztem obliczeniowym, więc może być zastosowana w trybie czasu rzeczywistego. Rekonstrukcja 3D urządzenie ułatwia operatorom jego dokładne zwymiarowanie, może być ponadto pomocna w opracowaniu strategii naprawy takiego uszkodzenia.

\section{Literatura}

[1] L. Ilcewicz, CS\&TA Federal Aviation Administration, 2006.

[2] J.R. Davis, ASM Handbook: Nondestructive evaluation and quality control,vol.17. ASM International, 1989.

[3] J. Deputat, S. Mackiewicz, J. Szelążek: Problemy i techniki nieniszczących badań materiałów: wybrane wykłady. Biuro Gamma, 2007.

[4] A. Lewińska-Romnicka: Badania nieniszczące: podstawy defektoskopii, Wydawnictwa Naukowo-Techniczne, 2001.

[5] A. Śliwiński: Ultradźwięki i ich zastosowania, Wydawnictwa NaukowoTechniczne, 2001.

[6] A. Katunin, K. Dragan, M. Dziendzikowski: Damage identification in aircraft composite structures: A case study using various non-destructive testing techniques, Composite Structures, Vol. 127, pp. 1-9, 2015.
[7] I. Pelianov, L. Ambrozinski, A. Khomenko, E. Koricho, G. Cloud, M. Haq, M. O'Donnell: High resolution imaging of impacted CFRP composites with a fiber-optic laser-ultrasound scanner. Photoacoustics, 2016.

[8] K. Dragan, M. Dziendzikowski, A. Leski.: Bezpośrednia diagnostyka kompozytowych elementów lotniczych z wykorzystaniem struktur inteligentnych. Przegląd Spawalnictwa, Vol. 87(12), 2015.

[9] R. Kaczmarek: Analiza dokładności wyznaczenia położenia nieciągłości punktowych w badaniach ultradźwiękowych z wykorzystaniem głowic podwójnych. Przegląd Spawalnictwa, Vol. 87(10), 2015.

[10] C. Xu, H. Wang: Ultrasonic fields and inspection of composites, Przegląd Spawalnictwa, Vol. 85(12), 2013.

[11] NDT Resource Center, http://www.ndt-ed.org/

[12] Olympus IMS, http://www.olympus-ims.com/ 